\title{
Determinants of SME location in a suburban area: Evidence from the Gdańsk-Gdynia-Sopot metropolitan area
}

Given the importance of small and medium enterprises (SMEs) in the European economy, it is essential to have adequate information about the various factors that determine their choice of location. However, the size of a company is often an aspect not covered in theoretical studies and empirical research on industrial locations and urban planning. This article examines the place of residence as a stimulator of SME development in suburbs. Multidisciplinary research carried out in the GdańskGdynia-Sopot Metropolitan Area, known as the Tricity, confirms this trend. The location determinants of SMEs in suburban areas were identified using a questionnaire. The survey was conducted in 251 enterprises located in seven municipalities with the highest suburbanisation rates within the Tricity. The study confirms that the municipalities characterised by the highest intensity of suburbanisation processes have higher business activity than other municipalities. Location decisions were largely made by business owners in line with behavioural theory. This means that SME owners more often consider personal factors than cost or demand factors. From the perspective of an entrepreneur, living conditions, the quality of public space, education and healthcare are significant.

Keywords: entrepreneurship, SME, suburban area, regional development, suburbanisation, Poland 


\section{Introduction}

Small and medium enterprises (SME) play a crucial role in national economies; they are the driving force of entrepreneurship, growth, innovation and competitiveness. This sector is widely considered the power that drives regional development and wellbeing. For local authorities and urban planners, proper spatial location requires adequate information about the various factors determining location choices. A company's location determines how it functions and influences its development, and may have a substantial impact on the firm's ability to establish and maintain a competitive advantage (Porter, 2000). Therefore, local, regional and national institutions as well as researchers have focused on identifying and studying the factors that determine companies' location behaviour. However, the size of a company is often neglected in theoretical studies and in empirical research on industrial location and urban planning. In addition, neither traditional nor neoclassical location theories account for company size. A survey of empirical studies on SME location behaviour shows that there still is a research gap in the literature, especially concerning eastern Europe. This was the reason for this study, with the objective of gaining insight into what determines SME location choices.

Development of the SME sector and the parallel process of urban sprawl in Poland were the impetus behind research on SME location choice in suburban areas. The Polish suburban zone has a very fragmented structure and a high rate of entrepreneurship in the SME sector (Martyniuk-Pęczek \& Pęczek, in press). This resulted from the socioeconomic changes in Poland after 1989, which were especially dynamic in suburban areas. The significant and continuous growth of such areas has been driven on the one hand by rapid development of small and medium enterprises, and on the other by both the "American way of life" and western European liberalism, which has significantly contributed to urban sprawl in Poland. The interrelationship between these two phenomena (SME development and suburbanisation) has resulted in the urban form of Poland's suburbs, which is distinctive for the Polish situation.

This study was divided into two parts: spatial and economic. The spatial part selected suburban municipalities in the Gdańsk-Gdynia-Sopot Metropolitan Area, known as the Tricity (Pol. Trójmiasto), with the highest intensity of suburbanisation and identified the influence of SMEs on spatial quality in selected suburban areas. The economic part identified the municipalities with the highest density of SMEs to determine the factors affecting SME location decisions.

This article is organised as follows. The following section briefly reviews the literature on location decisions and discusses the role of company size. It presents the results of statistical tests on a sample of 251 SMEs in the suburban area of the Tricity. To confirm the statistical tests, the results of a spatial analysis are also presented. The final section summarises the main conclusions.

\section{SME location factors: Literature review}

While searching for a place to conduct business, each enterprise chooses a location that will best provide for its needs. A suitable location can greatly enhance a company's market competitiveness with advantages such as increased production capacity, greater profit, expansion, better customer service, increased shareholder wealth and reduced costs (Mazzarol \& Choo, 2003). On the other hand, an unsuitable location can have adverse effects. Identifying and analysing enterprise location factors was part of the first location theories, which first focused on cost minimisation (Thunen, 1826; Launhardt, 1882; Predöhl, 1928; Weber, 1929), and then on market analysis and profit maximisation (Palander, 1935; Lösch, 1940; Hoover, 1948; Isard, 1956). In the second half of the twentieth century, a behavioural approach was introduced (Pred, 1967), according to which the explanation of how a location is selected takes into account the existence of a decision-maker, whose behaviour is characterised by bounded rationality. Currently, the choice of an enterprise's location is largely influenced by factors related to technological and social development (Van Noort \& Reijmer, 1999). However, it seems impossible to create a universal set of the factors influencing the decision on an enterprise's location. Moreover, even a hundred factors might be taken into account in making a location decision, but only a few of them are really important (Vlachou \& Iakovidou, 2015). The literature review shows that location factors can be grouped and divided in different ways. Shelley M. Kimelberg and Elizabeth Williams (2013), followed by Charisia Vlachou and Olga Iakovidou (2015), divide the vast literature devoted to identifying and explaining these factors into three categories: a) studies measuring the influence of a specific factor or set of factors on firm location decisions, b) studies explaining the location decision process for a specific industry or a business with specific characteristics and c) studies identifying the location factors influencing businesses in specific areas. An example by Peter Lloyd and Peter E. Dicken (1990), followed by Jouke van Dijk and Piet Pellenbarg (2000), who group factors into internal factors (e.g., quality of management, organisational goals, ownership structure, employment and profits), location factors (e.g., lot size, size of possible expansion space, and distance to customers and suppliers) and external factors (e.g., natural conditions, legal position, government policy and regional economic structure). 
There are other ways to group these factors. Some can be labelled "soft factors": these include unmeasurable, often subjective decision aspects such as the attitude of local authorities, economic profile of the location, social climate, quality of life, standard of living, and local arts and entertainment. The quality of public space and spatial order can also be included here. The second group is "hard factors", which are often measurable in relation to cost. They include the supply of production and office space, proximity to markets, energy purchases, proximity to suppliers and business partners, transport, qualified labour, regional taxes, subsidy policies, research and academic institutions, and the quality and flexibility of administration (Van Noort \& Reijmer, 1999; Leśniewski, 2012). In turn, Edwin Van Noort and Inge Reijmer divide location factors into three groups: those related to the commercial environment (presence of suppliers/customers, and presence of top business), physical environment (car and public transport accessibility, quality and the corporate image of the location, location size and the surrounding environment) and the institutional environment (incentives and environmental legislation; Risselada \& Schutjens, 2012). More recently, Yancy Vaillant et al. (2012) separated location factors into three groups: infrastructure and economic motivation, personal motivations and location-related motivations.

Certainly, the size of an enterprise influences the importance of a particular location factor. However, size is not taken into account in location theories nor in many empirical studies. Moreover, although much research has focused on large firms' decision-making processes, not much attention has been directed toward how SMEs make such decisions. Surely, micro, small and medium-sized enterprises differ from large companies, and in the context of location decisions these differences are related particularly to the decision-maker, to acquiring information about a particular location and to financial resources. Therefore, there is no theoretical framework explaining why small companies' behaviour does not mirror that of large ones. However, empirical evidence can be found in Barry Moore et al. (1991), Pauline Sullivan et al. (1998), Van Noort and Reijmer (1999), Josep-Maria Arauzo-Carod and Miguel ManjonAntolin (2004), Maria Teresa Costa et al. (2004) and Michał Flieger (2013). In a Europe-wide study by Moore et al. (1991), the most important factor influencing large and medium-sized enterprises' location decisions was the availability of regional development assistance, and for small companies access to customers (Moore et al., 1991). In turn, empirical evidence from Catalan municipalities shows that larger firms are guided by more objective decision-making reasons, whereas smaller ones are mostly oriented by the entrepreneur's preferences. In practice, the range of alternatives open to smaller firms is frequently reduced to the nearest geographical area (ArauzoCarod \& Manjon-Antolin, 2004). The choice of location by
SMEs in the Netherlands is not, contrary to that of large businesses, a strategic decision (Risselada \& Schutjens, 2012). It is usually short term. SMEs take only a limited number of diverse factors into account, which rarely applies to larger businesses. Moreover, "soft" factors (image and charisma) were relatively more important for large companies from the Netherlands than for SMEs (Risselada \& Schutjens, 2012). Sullivan et al. (1998) conclude that, in comparison with SMEs, large firms place the most importance on physical infrastructure, such as access to railroads, airports, ports or harbour facilities. They also place significantly greater importance on the availability of labour, as well as low-cost loans, public transport and favourable local labour costs. The findings of Chyi-lyi (Kathleen) Liang et al. (2001) indicate that small manufacturers' location decisions are often related to personal factors, including environment (quality of life) and local residence (the wish to remain close to home), access to capital, customers in the local and regional area, and the availability of facilities. A study of Australian SMEs by Valerie Kupke and John Pearce (1998) identified the two most important industrial location factors as proximity to the central business district and direct access to main roads.

Most surveys on the determinants of Polish companies' location decisions focus on identifying internal and external factors as well as the local advantages of the site, and to a smaller extent analysing their significance in relation to the size of a company (Budner, 2004; Godlewska, 2005; Płaziak \& Szymańska, 2014). In Polish studies, the size of enterprises has been considered by Małgorzata Poniatowska-Jaksch (1997), Flieger (2013), Mariola Chrzanowska and Nina Drejerska (2015) and Hanna Godlewska-Majkowska (2016). The Flieger (2013) study shows that for SMEs only the cost factors are significant (local fees, rent, labour cost and possibility of acquiring funds to support the business), but for large enterprises the factors associated with technological infrastructure, proximity to highways, labour costs and opportunities to cooperate with local enterprises are important. Building ownership by entrepreneurs was among the most frequent answers in the study by Poniatowska-Jaksch (1997). Chrzanowska \& Drejerska (2015) mentioned two location factors: proximity to the city and local market opportunities.

\section{Methodology and results 3.1 Methodology}

This study of suburbanisation and the development of SMEs was divided into two parts. From a spatial perspective, it singled out the suburban municipalities in the Tricity with the highest rate of suburbanisation and determines the form of development of individual plots. From the economic perspec- 


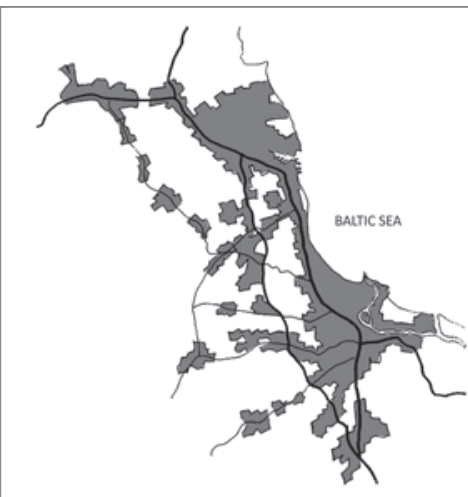

Spatial structure of the Tricity

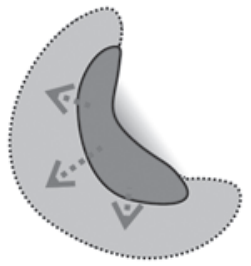

Step 1:

Migration analysis and construction activity index

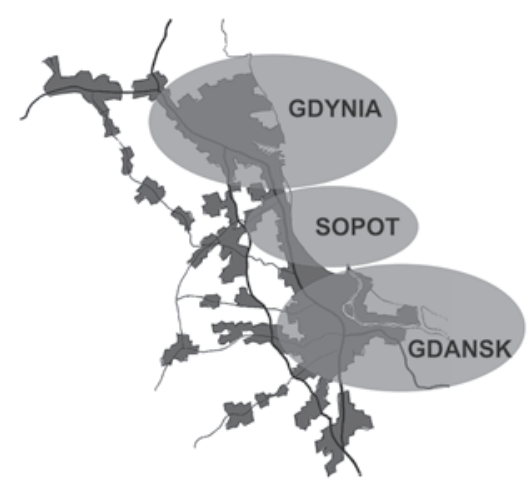

Core cities of the Tricity

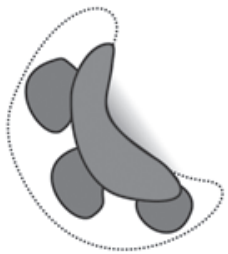

Findings

Municipalities with

the highest suburbanisation rate

Step 2:

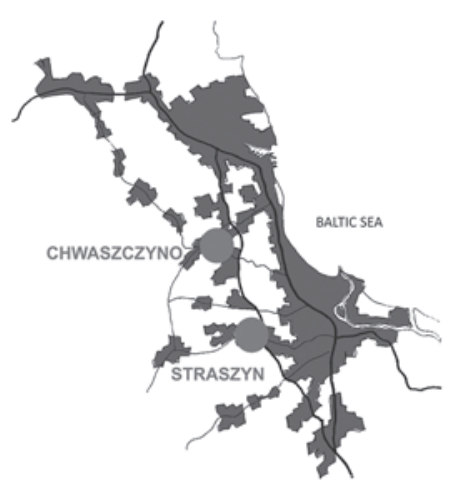

Suburban entrepreneurship clusters

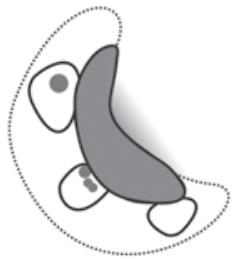

Findings

Municipalities with the highest degree

of SME concentration in relation

to the population concentration

Intensity of economic activity

measured by the location quotient (LQ) in a given area
$=$ Suburban entrepreneurship clusters

Figure 1: Identifying suburban entrepreneurship clusters based on the spatial structure of the Tricity (illustration: Justyna Martyniuk-Peczek).

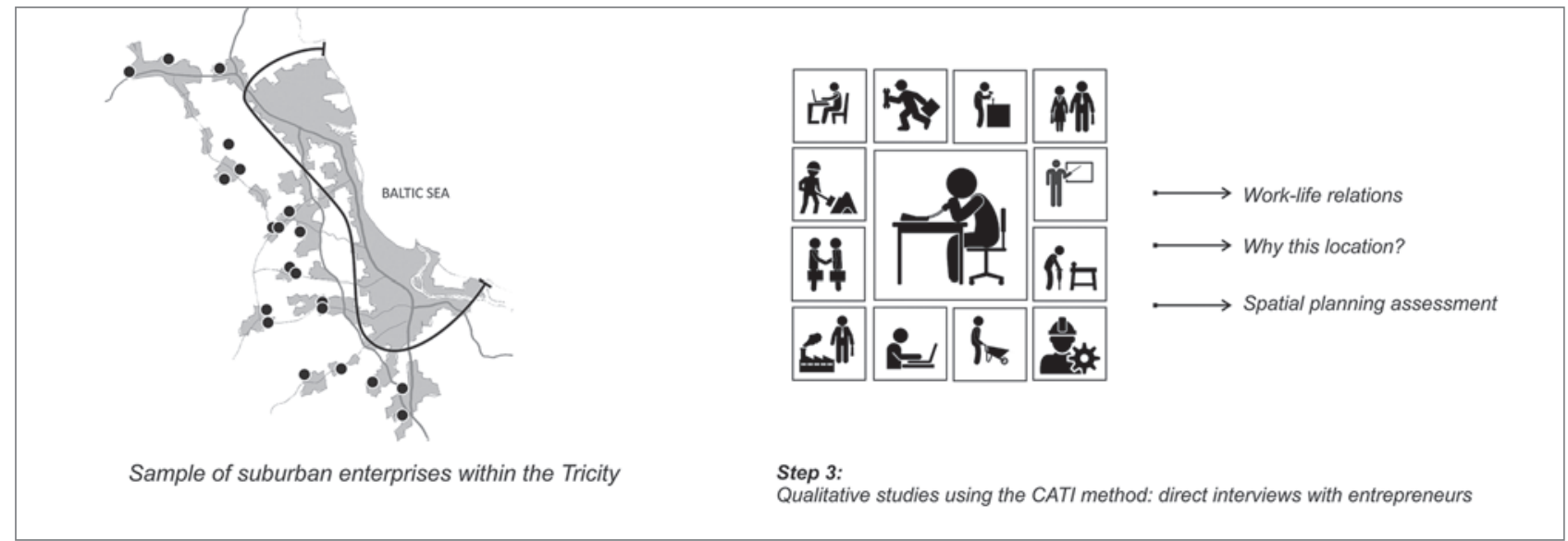

Figure 2: The qualitative study concept for selected suburban municipalities in the Tricity (illustration: Justyna Martyniuk-Peczek).

tive, it selected the municipalities or towns with the highest concentration of SMEs and identifies factors influencing the location decisions by SMEs operating there. The Tricity is a significant part of the functional and spatial structure of Pomerania and it is the most important economic and social centre of the south Baltic area. Pomerania ranks second among Poland's provinces in terms of entrepreneurship ${ }^{[1]}$. Around 7\% of all Polish SME-sector entities are registered in Pomerania.

To determine the suburbanisation rate, migration analysis from 2003 to 2012 and the construction activity index from 2008 to 2012 were used, based on statistical data. The intensity of economic activity was measured using a location quotient (LQ), which is a measure of the concentration of a given characteristic in a given area (in \% of the characteristic in general) in relation to the degree of population concentration in the given area (in of the total population).

In order to identify the location determinants of SMEs, a study using the CATI method was conducted in 2015 among 251 enterprises in the suburban areas of the Tricity ${ }^{[2]}$ that are most subject to suburbanisation processes and are characterised by the highest concentration of SMEs. Figure 2 illustrates the concept of this qualitative study, which was based on direct 


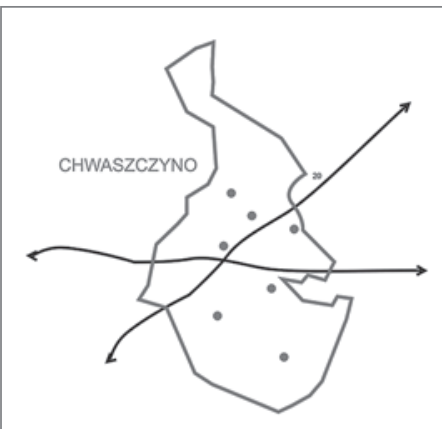

Chwaszczyno.

Suburban entrepreneurship nests in selected municipalities

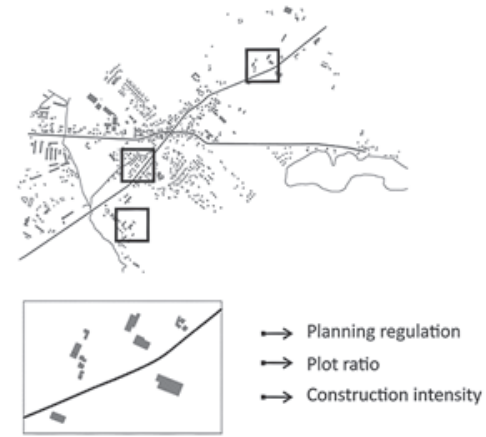

Step 4:

Spatial analysis of companies surveyed using the CATI method
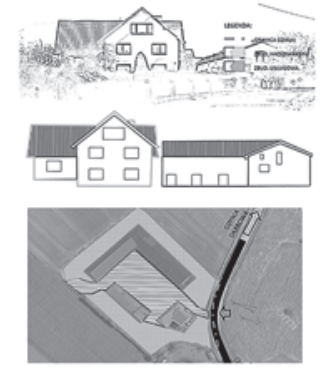

Findings by mixed use: residential and services

Figure 3: Three step research: analysis of urban planning and architectural forms of entrepreneurs' buildings chosen for the survey (illustration: Justyna Martyniuk-Peczek).

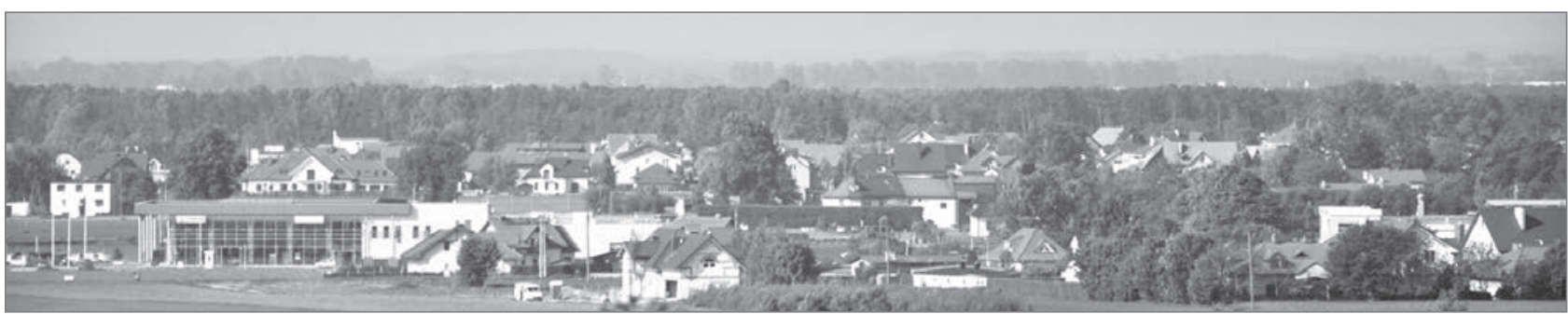

Figure 4: Residential fabric in Chwaszczyno with service buildings (photo: Grzegorz Peczek)

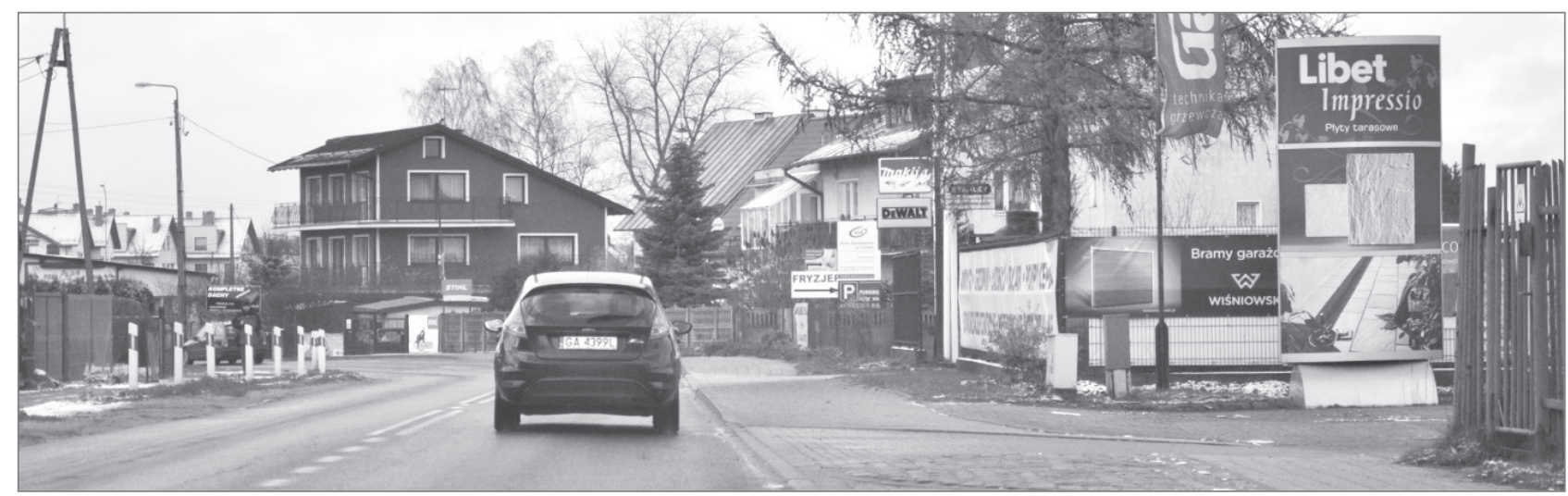

Figure 5: Chwaszczyno with outdoor advertising on the main street (photo: Grzegorz Peczek).

interviews with entrepreneurs. The illustration refers to the structure of the questionnaire used, which consisted of three parts (the first referred to work-life relations, the second to location criteria and the third to spatial planning assessment issues). A REGON (register of the entities of the national economy) number was used as a sampling frame. The sample was prepared based on a database of 3,500 companies from selected suburban areas of the Tricity. Purposive random sampling was used. A reserve of enterprises in case of an additional draw constituted $10 \%$ of the sample. Segmentation of the enterprises in the sample was subject to stratification by municipalities, towns and company size. The entities investigated were characterised as follows:

- Entities with two to nine employees (microenterprises, excluding self-employed); in the sample they constitut- ed $83.3 \%$ of all entities;

- Entities with ten to forty-nine employees (small enterprises); in the sample they constituted $14.7 \%$ of all entities;

- Entities with fifty to 249 employees (medium enterprises); in the sample they constituted $2 \%$ of all entities.

The results of the questionnaire reflect the findings for micro enterprises and, to a smaller extent, small enterprises. This is because micro and small enterprises comprised $98 \%$ of the sample enterprises. Such a composition of the sample is similar to that of Poland, where micro and small enterprises comprise $98.9 \%$ of all entities ${ }^{[3]}$. The largest groups in the sample were retail enterprises $(26.4 \%$ of all the entities investigated), industrial enterprises (18.3\%) and construction enterprises (11.2\%). 
Moreover, the strength of the correlations between company characteristics and the most important location determinants were measured. Correlations between the following company characteristics were examined: the size of an enterprise (micro, small or medium), the age of an enterprise (1-5, 6-15 or over 15 years old), the type of business activity (manufacturing, retail or services) and the type of company (family or non-family business), as well as variables indicating whether the place of residence and proximity to the place of residence helped determine the location decision. A chi-squared test, which compares the frequencies observed in the sample with the frequencies expected under an assumption of independence of the two variables, was used. In order to measure the strength of the correlation, Cramer's $V$ and Yule's phi were used. These have values between 0 and 1 , with values close to 0 indicating a weak correlation and values close to 1 a strong correlation.

Finally, in order to compare the qualitative survey results and reality, selected plots were examined in terms of urban planning and architecture (Figure 3). The goal was to examine whether SME location principles exist for individual plots.

Each one of the plots chosen for research was subject to identical spatial analyses. The following technical urban-planning parameters were used in the analysis: plot area, built up area, building height measured by the number of floors above ground, green space area, floor area ratio (FAR) and construction intensity. The traits characterising occurrence of buildings on plots with micro, small and medium-sized enterprise functions were sequentially examined. Three main layers were singled out for this analytical group: 1) the number of buildings on a plot, 2) presence of a residential building and 3) business activity conducted in a residential building. The purpose of this part of the analysis was to identify urban-architectural dependencies between residential development and conduction of business activity. The results of this research are presented in Table 4. Figures 4 and 5 illustrate the landscape of entrepreneurship clusters, in which the dominant form of structure is a low-density single-family house. What is characteristic for these locations is a vast density of outdoor advertising located in many plots (Figure 5).

The authors are aware of the imperfections of the research methods presented, which were selected to assess the suburbanisation process and economic activity. However, these weaknesses are independent of the authors and are primarily related to the manner of collecting statistical data in Poland. In the context of measuring the dynamics of migration, no obligation to report a change of address as well as the possibility of owning several homes in Poland may be considered such weaknesses, for instance. Analysis of construction activity is subject to an error associated with delays in registering completed buildings. The fact that the actual place of business activity is often different from the business entity's headquarters (place of registration) is a weakness associated with analysis of economic activity, which is based on the number of registered SME-sector companies.

\subsection{Results}

Comparing the data on migration balance and the construction activity index, seven municipalities in the Tricity with the most intensively developing suburbanisation process were singled out. Determining the location quotient measuring the degree of concentration of SME units in a given municipality in relation to population, in turn, made it possible to select two towns (Chwaszczyno and Straszyn) with the highest concentration of SMEs, and thus they can be referred to as "entrepreneurship clusters" for the Tricity (Martyniuk et al., 2016). A summary of the qualitative study results, showing the frequency of answers regarding whether a given factor was a determinant in an SME's location decision, is shown in Table 1. The correlations found to be statistically significant $(p<0.1)$ are shown in Table 2.

Based on the research, it can be concluded that business activity was carried out in or near the place of residence by threequarters of micro enterprises $(79.3 \%)$ and by almost half of small enterprises (48.6\%). This could be due to a lack of capital, local knowledge of market opportunities, or a need to begin creating personal contacts and networks that are only available in the "home" region. No English-language empirical studies of SME location factors in eastern Europe were found, and so it is impossible to critically discuss and link the findings with those of other researchers from this region, which would be appropriate. However, the conclusion that micro and small entities carry out business activity in the owner's place of residence was also indicated and confirmed in studies performed in western Europe by Rigoberto A. Lopez and Nona R. Henderson (1989), Liang et al. (2001), Tim Mazzarol and Stephen Choo (2003) and Anne Risselada and Veronique Schutjens (2012). Housing as a location factor was not identified by Kupke and Pearce (1998); however, their study was conducted in Adelaide, Australia in a significantly different economic and political region than the Tricity.

Polish studies on this subject in the Greater Poland region (Flieger, 2013) and in the province of Świętokrzyskie (Leśniewski, 2012) indicate the costs of business activity as a primary factor of location. However, it is difficult to compare these results because the surveys used by Leśniewski and Flieger do not mention criteria such as the place of residence. 
Table 1: Determinants of SMEs' location in suburban areas of the Tricity with the highest rate of suburbanisation.

\begin{tabular}{lllll}
\hline Determinant & Total results (\%) & Micro company (\%) & Small company (\%) & Medium-sized company (\%) \\
\hline Place of residence & 42.8 & 47.1 & 24.3 & 0.0 \\
\hline Proximity to core cities & 32.4 & 33.7 & 29.7 & 0.0 \\
\hline Proximity to place of residence & 30.4 & 32.2 & 24.3 & 0.0 \\
\hline Favourable transport conditions & 24.4 & 25.5 & 21.6 & 0.0 \\
\hline Personal reasons (family, childcare) & 19.6 & 21.6 & 10.8 & 0.0 \\
\hline Proximity to main client & 14.0 & 16.3 & 2.7 & 0.0 \\
\hline Infrastructure & 14.0 & 15.9 & 5.4 & 0.0 \\
\hline Demand & 14.0 & 15.9 & 5.4 & 0.0 \\
\hline Low investment costs & 10.0 & 9.6 & 10.8 & 20.0 \\
\hline Low price of land & 8.0 & 8.2 & 8.1 & 0.0 \\
\hline Natural conditions of area & 6.0 & 7.2 & 0.0 & 0.0 \\
\hline Low transport costs & 5.6 & 6.3 & 2.7 & 0.0 \\
\hline Low labour costs & 4.8 & 4.8 & 5.4 & 0.0 \\
\hline Previous location analysis & 4.8 & 5.3 & 2.7 & 0.0 \\
\hline Access to raw materials & 2.8 & 3.4 & 0.0 & 0.0 \\
\hline Availability of discounts for entre- & 2.0 & 2.4 & 37.8 & 0.0 \\
\hline preneurs & 23.2 & 19.2 & 0.0 \\
\hline Other & & & 0.0 \\
\hline So & & & 0.0 & \\
\hline
\end{tabular}

Source: Own calculations based on the questionnaire.

Table 2: Correlations between company characteristics and place of residence, and correlations between company characteristics and proximity to place of residence.

\begin{tabular}{|c|c|}
\hline \multicolumn{2}{|c|}{$\begin{array}{l}\text { 1. Size of company and place of residence as a location determinant } \\
\qquad p=0.019 \text {, Cramer's V }=0.20\end{array}$} \\
\hline Company size & Percentage of entities in the sample indicating place of residence as a determinant of location \\
\hline Micro & $47 \%$ \\
\hline Small & $24 \%$ \\
\hline Medium & $0 \%$ \\
\hline \multicolumn{2}{|c|}{ 2. Type of company and place of residence as a location determinant } \\
\hline Company type & Percentage of entities in the sample indicating place of residence as a determinant of location \\
\hline Family business & $58 \%$ \\
\hline Non-family business & $32 \%$ \\
\hline \multicolumn{2}{|c|}{ 3. Type of company and proximity to place of residence as a location determinant } \\
\hline Company type & $\begin{array}{l}\text { Percentage of entities in the sample indicating proximity to place of residence as a determinant } \\
\text { of location }\end{array}$ \\
\hline Family business & $37 \%$ \\
\hline Non-family business & $26 \%$ \\
\hline
\end{tabular}

Source: Own calculations based on the questionnaire. 
Table 3: Correlations between company characteristics and proximity to core cities.

\begin{tabular}{|c|c|}
\hline \multicolumn{2}{|c|}{$\begin{array}{l}\text { 1. Type of business activity and proximity to core cities as a location determinant } \\
\qquad p=0.037 \text {, Cramer's V }=0.16\end{array}$} \\
\hline Type of business activity & Percentage of entities in the sample indicating proximity to core cities as a determinant of location \\
\hline Manufacturing & $35 \%$ \\
\hline Retail & $40 \%$ \\
\hline Services & $22 \%$ \\
\hline \multicolumn{2}{|c|}{ 2. Type of company and proximity to core cities as a location determinant } \\
\hline Company type & Percentage of entities in the sample indicating proximity to core cities as a determinant of location \\
\hline Family business & $43 \%$ \\
\hline Non-family business & $25 \%$ \\
\hline
\end{tabular}

Source: Own calculations based on the questionnaire.

The second factor influencing location decisions that was indicated by the respondents was proximity to the core cities (Gdańsk, Sopot and Gdynia). The correlations found to be statistically significant using the chi-squared test $(p<0.1)$ are shown in Table 3. Because previous studies that connect location factors with special areas mostly concern urban areas (Karakaya \& Canal, 1998; Cohen, 2000; Prat \& Marcen, 2006) or rural areas (Michelacci \& Silva, 2007; Yu \& Artz, 2009; Vaillant et al., 2012), and not suburban areas, it is impossible to critically discuss and link our findings with those of international researchers. However, suburban areas in the context of location factors of SMEs were analysed by Poniatowska-Jaksch (1997) and Chrzanowska \& Drejerska (2015). Both studies examined the Warsaw suburban area. Our results are consistent with those concerning Warsaw in the case of proximity to the core city as an important location factor.

Another factor influencing the location decisions of SMEs in suburban areas of the Tricity was favourable transport conditions. A statistically significant correlation was found between the type of company and whether a favourable transport system was a determinant of location ( $p=0.021$, Yule's phi $=0.15$ ). Overall, $25.5 \%$ of microenterprises and $21.6 \%$ of small enterprises in the sample indicated favourable transport conditions as the determinant of location. The role of transport has a long tradition in classical location theory. Among the various types of transport infrastructure, roads are frequently reported as the most important type. Although firms perceive the availability of good transport infrastructure as very important, it is seldom the decisive factor in a location decision. This statement agrees with the findings of Moore et al. (1991) in relation to SMEs. In their research, infrastructure was found to be relatively unimportant as a locational determinant. Sullivan et al. (1998) state that for SMEs, in comparison to large firms, infrastructure plays a less important role. The same conclusions were indicated in Polish studies carried out by Flieger (2013).
Our qualitative results are similar to the findings of the Polish survey (Leśniewski, 2012).

Subsequently, in order to confirm our findings from the economic section, we conducted an urban-planning analysis. This analysis determined types of urban fabric and assigned them characteristic features that describe their construction parameters (Figure 6). The upper row of the figure shows the predominant building type (typical forms of mixed-use buildings), and the lower row presents low-density buildings (detached houses and various forms of service buildings). The results show that most plots are relatively large; that is, 1,200 to $3,500 \mathrm{~m}^{2}$, and sometimes even $9,000 \mathrm{~m}^{2}$. Such an area is characteristic of the extensive use of space in suburbs. The second characteristic trait for this type of system is the relatively low percentage of buildings, in most cases not exceeding $20 \%$ of the plot area. As a consequence, building development is extensive in nature, and its intensity ranges from 0.1 to 0.5 . Such construction and urban fabric is characteristic of the suburban Polish landscape and shows a great lack of spatial order.

This might be a result of legal conditions for developing suburban areas in Poland. The legal foundations for locating buildings tend to vary widely even between closely neighbouring areas, which is a consequence of the post-communist transformation in Poland. The transformation of spatial planning was carried out in three phases (Kolipiński, 2014): 1) an adjustment/preparation phase from 1989 to 1994, 2) application of a new model from 1995 to 2003 and 3) a system correction phase, which is still ongoing. The legal conditions for the development locations therefore naturally followed these phases.

The first structures erected directly after the collapse of communism in 1989 were sited based on the spatial planning law and plans from the previous system (Izdebski et al., 2007; Dutkowski, 2012; Kolipiński, 2014). Local planning was based 


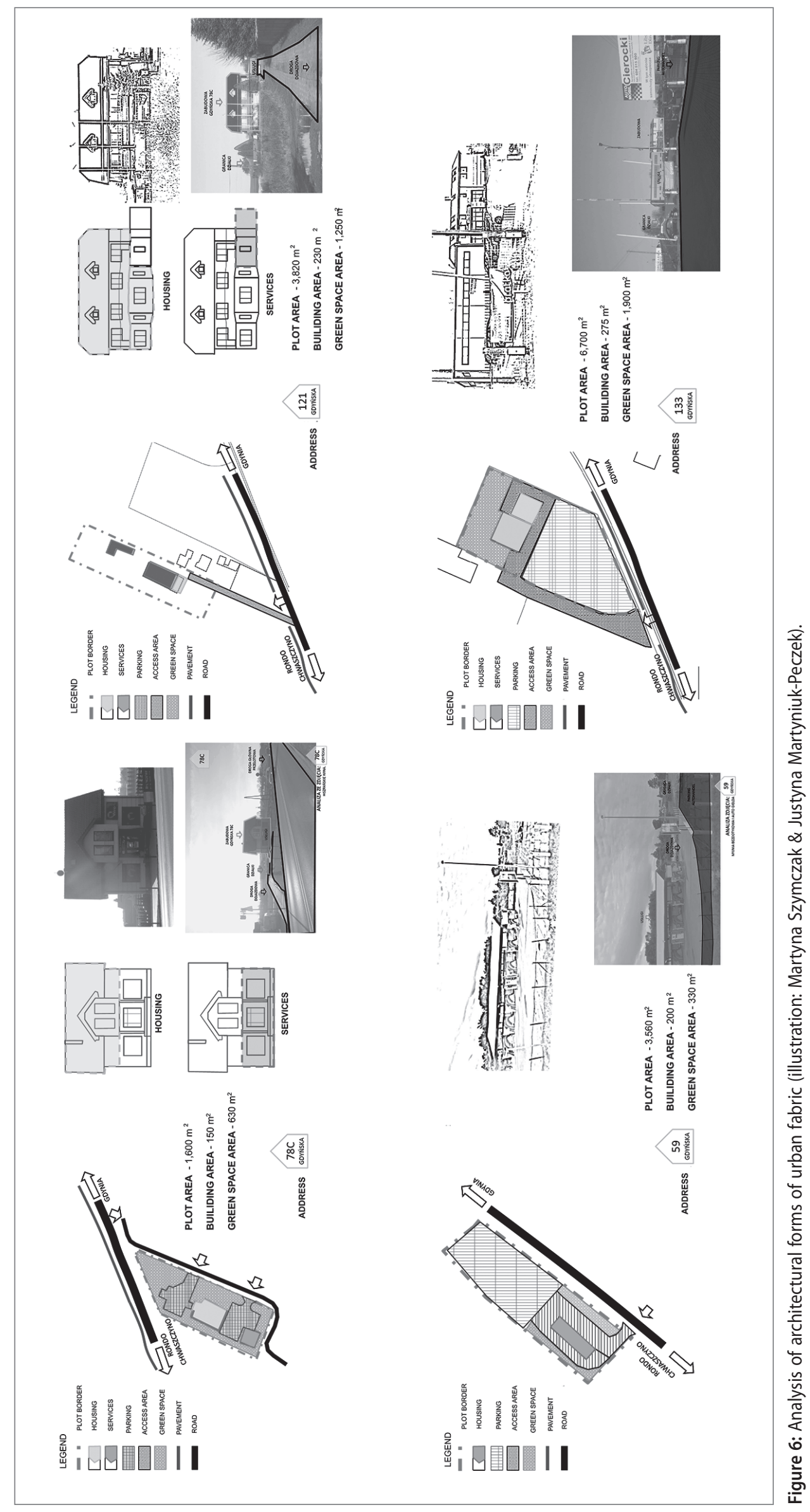


Table 4: Selected urban parameters and results for Chwaszczyno and Straszyn

\begin{tabular}{|c|c|c|c|c|c|c|}
\hline Town/city & Street address & Plot area $\left(\mathrm{m}^{2}\right)$ & $\%$ of buildings & No. of buildings & $\begin{array}{l}\text { Residential } \\
\text { buildings }\end{array}$ & $\begin{array}{l}\text { Business activity in a } \\
\text { residential building }\end{array}$ \\
\hline \multirow{18}{*}{$\begin{array}{l}\text { Chwasz- } \\
\text { czyno }\end{array}$} & Wąska 21 & 4,300 & 13 & 2 & 0 & 0 \\
\hline & Polna 9 & 9,130 & 19 & 3 & 1 & 0 \\
\hline & Ogrodowa 3 & 1,130 & 18 & 1 & 1 & 1 \\
\hline & Oliwska 92 & 356 & 24 & 1 & 1 & 1 \\
\hline & Gdyńska 78 & 4,200 & 14 & 3 & 1 & 0 \\
\hline & Gdyńska 78C & 1,600 & 9 & 1 & 1 & 1 \\
\hline & Gdyńska 94 & 1,630 & 9 & 1 & 0 & 0 \\
\hline & Gdyńska 59 & 3,560 & 6 & 1 & 0 & 0 \\
\hline & Wąska 23 & 1,640 & 23 & 1 & 1 & 0 \\
\hline & Jarzębinowa 5 & 865 & 26 & 1 & 1 & 1 \\
\hline & Świerkowa 72 & 1,200 & 14 & 1 & 1 & 1 \\
\hline & Sienkiewicza Henryka 2 & 830 & 18 & 1 & 1 & 1 \\
\hline & Norwida Cypriana Kamila 14 & 790 & 18 & 1 & 1 & 1 \\
\hline & Sychty Bernarda 18 & 630 & 27 & 2 & 1 & 0 \\
\hline & Majkowskiego 2 & 815 & 29 & 2 & 1 & 1 \\
\hline & Gdyńska 133 & 6,270 & 4 & 1 & 0 & 0 \\
\hline & Gdyńska 121 & 3,820 & 22 & 3 & 1 & 0 \\
\hline & Kaszubska Droga 5 & 1,320 & 10 & 2 & 1 & 1 \\
\hline \multirow{15}{*}{ Straszyn } & Różana 19 & 512 & 25 & 2 & 1 & 1 \\
\hline & Meblowa 10 & 3,500 & 46 & 3 & 0 & 0 \\
\hline & Liliowa 4 & 605 & 13 & 1 & 1 & 1 \\
\hline & Świerkowa 27 & 675 & 16 & 1 & 1 & 1 \\
\hline & Młyńska 7 & 8,000 & 35 & 5 & 0 & 0 \\
\hline & $\begin{array}{l}\text { Starogardzka 42-44, buil- } \\
\text { ding A }\end{array}$ & 4,730 & 36 & 2 & 0 & 0 \\
\hline & Tęczowa 1 & 465 & 26 & 1 & 1 & 1 \\
\hline & Liliowa 5 & 850 & 22 & 2 & 1 & 1 \\
\hline & Szafirowa 11 & 1,200 & 13 & 1 & 1 & 1 \\
\hline & Starogardzka 38 & 1,130 & 27 & 1 & 0 & 0 \\
\hline & Spokojna 68 & 2,580 & 10 & 2 & 1 & 1 \\
\hline & Ogrodowa 19 & 600 & 18 & 1 & 1 & 1 \\
\hline & Objazdowa 5 & 3,445 & 18 & 2 & 0 & 0 \\
\hline & Starogardzka 22 & 705 & 23 & 1 & 1 & 1 \\
\hline & Spokojna 52 & 3,450 & 30 & 1 & 0 & 0 \\
\hline
\end{tabular}

Source: Own calculations based on spatial analysis.

on local municipal authorities taking over the jurisdiction of former municipal national councils together with the former plans that were still in force, regardless of their quality level. The development carried out later in the 1990s was merely single buildings sited on the basis of location permits granted individually, mostly with no connection to some overall plan or vision (Solarek, 2013). This situation and method exacerbated the chaotic and scattered spatial structure in the suburbs (Lisowski \& Grochowski, 2009). In contrast, the last ten years could be described as an attempt to harmonise local zoning plans more strictly with higher-order planning documents as well as with other zoning plans that were created previously (Solarek, 2013). This was an attempt to connect the existing building structure with that being planned; for example, to be converted from farm use to other uses. However, this resulted in an oversupply of investment land converted from farm use, which consequently caused more scattering of the built structure rather than condensing it (Lisowski \& Grochowski, 2009).

The survey carried out among entrepreneurs confirmed the findings of our spatial research. We sought to answer the following questions based on spatial analysis:

- Does residential development always accompany the 
building where business activity is conducted? (80\% answered yes)

- How often does business activity occur in residential buildings? (in over 55\%)

- Do the plots have only residential buildings in which business activity is conducted (i.e., adaptation of part of a house for business activity)? The share is over 30\%. Typically, plot areas were significantly smaller than in other cases and did not particularly correspond to an average residential property; that is, around $800 \mathrm{~m}^{2}$.

Table 4 presents selected parameters and the results of building structure and plot development analysis for two different towns: Chwaszczyno and Straszyn.

\section{Conclusion}

The suburbanisation processes taking place in various countries in Europe are not homogeneous. This is because suburban areas in different countries are shaped by different social, economic and spatial factors. In the spatial context, Poland-specific characteristics comprise the lack of a tradition of "efficient" land use, the lack of local practices and standards for the use of space, and weakness in spatial planning, mainly at the local scale, manifesting itself in freedom in preparing spatial development plans and ease in altering them (Fogel, 2012). The spatial form presented by Polish urban sprawl does not follow appropriate urban standards in terms of spatial order. It is often described as expansive, unstructured or chaotic. One reason for this may be the specific economic character of Polish suburban areas; namely, the high activity of SMEs, which have increased in number over the last twenty-five years (Martyniuk et al., 2016; Martyniuk-Pęczek \& Pęczek, in press). The flow of citizens with entrepreneurial orientations away from the core cities has caused Polish suburban areas to become "entrepreneurship clusters". Based on previous studies conducted in Poland, it can be suggested that "entrepreneurship clusters" are formed in the areas where business activity entails the lowest costs (low price of land, rent and labour) or guarantees a high demand. However, our findings suggest that local authorities and urban planners seeking to develop and market land in suburban areas need to devote attention to the quality of living conditions, including transport and public space. When people with a strong entrepreneurial attitude consider locating business activity in a suburban area, they prefer a location that provides appropriate living conditions for their family over the cost aspect. This can be particularly important for SMEs in suburban areas because proximity to core cities guarantees demand. As a result, entrepreneurs that search for a location for their business do not choose places with the lowest costs of business activity, but those that can ensure development of their businesses and for their families. However, it is important to note that quality expectations in Poland, in the context of living conditions and public space, seem to be much lower than in western Europe.

The fact that this research was carried out in suburban areas of only one metropolitan area is a limitation of this study. It means that all of the findings described above can only be applied to suburban areas of the Tricity. Studies of other metropolitan areas in Poland could confirm or reject the statement that decisions about locating SMEs in suburban areas favour personal reasons over costs.

Justyna MARTYNIUK-PĘCZEK

Gdańsk University of Technology, Faculty of Architecture, Department of Urban and Regional Planning, Gdańsk, Poland E-mail: juspecze@pg.gda.pl

\section{Olga MARTYNIUK}

University of Gdańsk, Faculty of Management, Department of Corporate Finance, Sopot, Poland

E-mail: omartyniuk@ug.edu.pl

\section{Anna GIERUSZ}

University of Gdańsk, Faculty of Management, Department of Statistics, Sopot, Poland

E-mail: anna.gierusz@ug.edu.pl

\section{Grzegorz PĘCZEK}

Sopot University of Applied Sciences, Faculty of Architecture, Sopot, Poland

E-mail: g.peczek@ssw.sopot.pl

\section{Acknowledgements}

This article was written as part of project UMO-2013/09/B/HS4/01175, financed by the National Science Centre in Poland.

\section{Notes}

[1] The ranking of the provinces is based on a synthetic index. The synthetic index of entrepreneurship development in the regions was created based on the place a given region held in twenty-six categories of variables referring to entrepreneurship development, including the number of enterprises, the number of people working in enterprises, the revenues, the expenses and the investment expenditure (Cieslik et al.,2014).

${ }^{[2]}$ The area's limits were selected according to the Development Plan of Pomerania.

${ }^{[3]}$ Data as of 31 December 2013.

\section{References}

Arauzo-Carod, J. M. \& Manjon-Antolin, M. C. (2004) Firm size and geographical aggregation: An empirical appraisal in industrial location. Small Business Economics, 22(3-4), pp. 299-312. DOI: 10.1023/B:SBEJ.0000022216.09083.76 
Budner, W. (2004) Location of enterprises. Aspects of economic and spatial and environmental. Poznań, Wydawnictwo Akademii Ekonomicznej w Poznaniu.

Chrzanowska, M. \& Drejerska, N. (2015) Małe i średnie przedsiębiorstwa w strefie podmiejskiej Warszawy-określenie znaczenia lokalizacji z wykorzystaniem drzew klasyfikacyjnych. Prace Naukowe Uniwersytetu Ekonomicznego we Wrocławiu, 385, pp. 45-52. DOI: 10.15611/ pn.2015.385.05

Cieślik, J., Czarzasty, J., Dąbrowski, J., Koładkiewicz, I., Konieczna-Sałamatin J., Łapiński, J., et al. (2014) Raport o stanie sektora małych i średnich przedsiębiorstw w Polsce w latach 2012 - 2013. Warsaw, Polska Agencja Rozwoju Przedsiębiorczości.

Cohen, N. (2000) Business location decision-making and the cities: Bringing companies back. Washington, DC, Brookings Institution Center on Urban and Metropolitan Policy.

Costa, M. T., Segarra, A. \& Viladecans E. (2004) Business dynamics and territorial flexibility. Small Business Economics, 22(3/4), pp. 265-281.

Dicken, P. \& Lloyd, P. E. (1990) Location in space: Theoretical perspectives in economic geography. New York, Harper \& Row.

Dutkowski, M. (2012) System planowania przestrzennego, Akademie für Raumforschung und Landesplanung (ARL). Available at: https://www. arl-net.de/commin/poland-polska/11-historia-planowania-przestrzennego (accessed 1 Jul. 2016).

Flieger, M. (2013) The criteria and barriers to location of business in the process of stimulating the development of the municipalities - empirical results. Research Papers of the Wrocław University of Economics, 284, pp. 27-215.

Fogel, P. (2012) Indicators of politics and spatial planning in municipalities. Bulletin PAN KPZK, 250, pp. 8-260.

Godlewska, H. (2005) Determinants of location decisions. Warsaw, Wyższa Szkoła Menadżerska.

Godlewska-Majkowska, H. (2016) Powiązania strukturalne a podejmowanie decyzji lokalizacyjnych w małych przedsiębiorstwach. Prace Komisji Geografii Przemysłu Polskiego Towarzystwa Geograficznego, 30(1), pp. 47-61.

Hoover, E. M. (1948) The location of economic activity. New York, McGraw-Hill.

Isard, W. (1956) Location and space-economy. New York, J. Wiley and Sons.

Izdebski, H., Nelicki, A. \& Zachariasz, I. (2007) Zagospodarowanie przestrzenne. Polskie prawo na tle standardów demokratycznego państwa prawnego. Warsaw, Ernst \& Young.

Karakaya, F. \& Canel, C. (1998) Underlying dimensions of business location decisions. Industrial Management and Data Systems, 98(7), pp. 321-29. DOI: 10.1108/02635579810205395

Kimelberg, S. M. \& Williams, E. (2013) Evaluating the importance of business location factors: The influence of facility type. Growth and Change, 44(1), pp. 92-117. DOI: 10.1111/grow.12003

Kolipiński, B. (2014) Planowanie przestrzenne w Polsce w minionym 25-leciu. MAZOWSZE Studia Regionalne, 2014(15), pp. 109-118.

Kupke, V. \& Pearce, J. (2000) Identifying industrial location and site preferences for small business. Pacific Rim Property Research Journal, 6(1), pp. 12-23. DOI: 10.1080/14445921.2000.11104080

Leśniewski, M. A. (2012) Factors location of the enterprises - empirical results. Studia i Prace Kolegium Zarządzania, 113, pp. 117-133.

Liang, C. L. K., Su, Y. T., Dunn, P. \& Halbrendt, C. (2001) A nonparametric approach to study key factors influencing location decisions for small manufacturing enterprises in Vermont. Paper presented at the Second
Annual USASBE/SBIDA Joint National Conference, 7-10 February, Orlando, FL. Typescript.

Lisowski, A. \& Grochowski, M. (2009) Procesy suburbanizacji. Uwarunkowania. Formy i konsekwencje. Ekspertyzy do Koncepcji Zagospodarowania Przestrzennego Kraju, Tom 1 (2009), Warsaw, Ministerstwo Rozwoju Regionalnego, pp. 217-281.

Lopez, R. A. \& Henderson, N. R. (1989) The determinants of location choices for food processing plants. Agribusiness, 5(6), pp. 619-632. DOI: 10.1002/1520-6297(198911)5:6<619::AIDAGR2720050607>3.0.CO;2-A

Lösch, A. (1940) Die räumliche Ordnung der Wirtschaft. Jena, Gustav Fischer.

Martyniuk, O., Martyniuk-Pęczek, J. \& Pęczek, G. (2016) Economic vitality of Polish suburbs. GSTF Journal of Engineering Technology (JET), 3(4), pp. 39-48.

Martyniuk-Pęczek, J. \& Pęczek, G. (in press) Spatial structure of the suburban zones in selected entrepreneurship nests of the Tricity metropolitan area. Keeping Up with Technologies to Make Cognitive City. Newcastle upon Tyne, Cambridge Scholars Publishing.

Mazzarol, T. \& Choo, S. (2003) A study of the factors influencing the operating location decisions of small firms. Property Management, 21(2), pp. 190-208. DOI: 10.1108/02637470310478918

Michelacci, C. \& Silva, O. (2007) Why so many local entrepreneurs? The Review of Economics and Statistics, 89(4), pp. 615-633. DOI: 10.1162/rest.89.4.615

Moore, B., Tyler, P. \& Elliott, D. (1991) The influence of regional development incentives and infrastructure on the location of small and medium sized companies in Europe. Urban Studies, 28(6), pp. 1001-1026. DOI: 10.1080/00420989120081171

Palander, T. (1935) Beiträge zur standortstheorie. Uppsala, Almqvist \& Wiksell.

Poniatowska-Jaksch, M. (1997) Wpływ czynników lokalizacyjnych na wzrost aktywności gospodarczej w strefie podmiejskiej Warszawy w świetle badań ankietowych. Monografie i Opracowania/Szkoła Główna Handlowa, 411, pp. 134-166.

Porter, M. E. (2000) Location, competition, and economic development: Local clusters in a global economy. Economic Development Quarterly, 14(1), pp. 15-34. DOI: 10.1177/089124240001400105

Prat, J. C. R.-S. \& Marcén, R. F. (2006) Influential factors in location choice of Spanish businesses in Aragon. Journal of Entrepreneurship, 15(1), pp. 63-81. DOI: 10.1177/097135570501500105

Pred, A. R. (1967) Behaviour and location: Foundations for a geographic dynamic location theory. Part 1. Studies in Geography, Series B. 27. Lund, University Lund.

Predöhl, A. (1928) The theory of location in its relation to general economics. Journal of Political Economy, 36(3), pp. 371-390. DOI: $10.1086 / 253950$

Risselada, A. H. \& Schutjens V. (2012) Firm location behaviour in the new economy: Understanding the role of property factors in location decisions of neighbourhood firms. Paper presented at the Third ECFED International Workshop, 14-15 June, Namur, Belgium. Typescript.

Solarek, K. (2013) Struktura przestrzenna strefy podmiejskiej Warszawy. Determinanty współczesnych przekształceń. Warsaw, Oficyna Wydawnicza Politechniki Warszawskiej.

Sullivan, P., Halbrendt, C. \& Buescher, M. (1998) Small business location considerations for agriculture and forestry sectors. Paper presented at the International Council for Small Businesses 43rd World Conference, 8-10 June, Singapore. Typescript. 
Vaillant, Y., Lafuente, E. \& Serarols, C. (2012) Location decisions of new 'knowledge intensive service activity' firms: the rural-urban divide. The Service Industries Journal, 32(16), pp. 2543-2563.

DOI: $10.1080 / 02642069.2011 .594880$

Van Dijk, J. \& Pellenbarg, P. (2000) Firm relocation decisions in the Netherlands: An ordered logit approach. Regional Science, 79(2), pp. 191-219. DOI: 10.1007/s101100050043

Van Noort, E. A. \& Reijmer, I. A. (1999) Location choice of SMEs: The most important determinants. Zoetermeer, EIM Small Business Research and Consultancy.

Vlachou, C. \& lakovidou, O. (2015) The evolution of studies on business location factors. Journal of Developmental Entrepreneurship, 20(4), pp. 1-23. DOI: 10.1142/S1084946715500235

Von Thünen, J. H. (1875) Der isolierte Staat in Beziehung auf Landwirtschaft und Nationalökonomie (Vol. 1). Wiegant, Hempel \& Parey. DOI: 10.5962/bhl.title.24798

Weber, A. (1929) Theory of the location of industries. Transl. C. J. Friedrich. Chicago, University of Chicago Press. Available at: https://archive. org/details/alfredweberstheo00webe (accessed 6 Jul. 2016).

Yu, L. \& Artz, G. (2009) Migration and rural entrepreneurship, Working paper no. 09017. Ames, IA, lowa State University. Available at: http://lib.driastate.edu/econ_las_workingpapers/142/ (accessed 10 Jul. 2016). 